\title{
Herman Dooyeweerd 1894-1977
}

\author{
M. Elaine Botha \\ Departement Filosofie \\ $\mathrm{PU}$ vir $\mathrm{CHO}$ \\ POTCHEFSTROOM
}

Die honderdjarige herdenking van die geboortedag van die Nederlandse filosoof, Herman Dooyweerd, is in 1994 in verskeie wêrelddele gevier deur 'n aantal mylpaalkongresse en publikasies. In 'n tyd waarin sogenaamde meta-verhale van alle kante bevraagteken word, is die vitaliteit van die reformatoriese tradisie in die filosofie 'n ontwikkeling wat groot rede tot dankbaarheid gee.

In Augustus 1994 het in Hoeven in Nederland die internasionale Dooyeweerd-Simposium, "Christian Philosophy at the Close of the Twentieth Century", plaasgevind waar referate oor 'n verskeidenheid onderwerpe deur sprekers van verskeie wêrelddele gelewer is. Die Simposium is bygewoon deur sowat 130 mense afkomstig uit onder andere Finland, Korea, Sjina, Moskou, Argentinië, Korea, Noord-Amerika en verskeie lande in Europa en Afrika. Wat veral opvallend was, was die aanwesigheid van verskeie filosowe uit ander Christelik-filosofiese tradisies, onder andere Alvin Plantinga van die Universiteit van Notre Dame en Nicholas Wolterstorff van die Universiteit van Yale in die VSA. Verblydend was ook die groot groep jonger akademici uit alle wêrelddele wat die Simposium bygewoon het, ook vanuit Suid-Afrika. Vir die eerste keer is 'n Dooyeweerdprys uitgeloof vir die beste publikasie in hierdie tradisie die afgelope vyf jaar. Hierdie prys is toegeken aan die jong Finse filosoof, Tapio Puolimatka, wat op eie stoom die filosofie van Dooyeweerd ontdek het en aan die Universiteit van Helsinki gepromoveer het met 'n proefskrif oor: "Moral Realism and Justification". Nadat hy Christen geword het, het hy gesoek na 'n filosofie waarvan die uitgangspunte in die verlengde van sy eie geloofsoortuigings sou lê. Sy lewensverhaal en soeke was vir die aanwesiges 'n geweldige inspirasie en aanmoediging gewees. Die werk van Dooyeweerd word tans onder meer in Spaans vertaal omdat daar in hierdie taalgebied ook heelwat belangstelling vir sy filosofie ontwikkel het. 
Die jaar 1994 is ook gekenmerk deur die totstandkoming van die Dooyeweerd Navorsingsentrum by Redeemer College in Ancaster, Ontario, Kanada. By dié openingsgeleentheid het Evan Runner, emeritusprofessor van Calvin College, Grand Rapids, in die VSA gepraat oor "The World-historical Importance of Dooyeweerd's Christian Philosophy". Prof. D.F.M. Strauss, hoogleraar in Filosofie van die UOVS in SuidAfrika, is as eerste Direkteur van hierdie Sentrum aangestel vir 'n periode van twee jaar met die taak om juis die erfenis van die reformatoriese filosofie uit te bou en te werk aan die verdere vertaling van Herman Dooyeweerd se werke in Engels.

Later in 1994 is daar aan die Vrije Universiteit van Amsterdam in Nederland ook 'n Dooyeweerd-Herdenkingskongres gehou waartydens verskeie Nederlandse en ander akademici bydraes gelewer het en 'n boek oorhandig is met die titel: Dooyeweerd 1894-1977. Breadth and Relevance of his Philosophy.

Aan die PU vir CHO het die Departement Filosofie in 1994 sy jaarlikse Stokerlesings onder andere gewy aan die werk van Herman Dooyeweerd en die reformatoriese wysgerige tradisie. Wat kenmerkend was van hierdie kongres was veral die deelname van jonger filosowe en die wye spektrum van onderwerpe wat deur hierdie deelnemers sowel in asook vanuit die Calvinistiese wysbegeerte benader en behandel is. Nie al die lesings wat in hierdie nommer van Koers opgeneem is, is by dié geleentheid gelewer nie. Die Departement Filosofie het egter wel gepoog om soveel moontlik jonger akademici aan te moedig om bydraes vir hierdie bundel voor te berei ten einde dan ook veral uit hierdie geledere belangstelling in die reformatoriese filosofie te bevorder. Die inhoud van hierdie bundel is verteenwoordigend van die bydraes wat by dié besondere kongres gelewer is asook van ander bydraes wat vir dié doel in hierdie nommer ingesluit word.

Die leser sal gou opmerk dat die reeks onderwerpe wat in hierdie Koersnommer behandel word wyd uiteenlopend is. Deurlopend is egter die konfrontasie met moderne kultuurtendense, by name die postmodernisme en pluralisme, modeme kultuurproblematiek soos staatsgeweld en omgewingsetiek asook onlangse ontwikkelinge en diskussies oor aspekte van die werk van Dooyweerd en andere binne die reformatoriese tradisie. Sentraal staan in hierdie konfrontasie die diskussie rondom die wetsidee en die rol van die Skrif in die filosofie. Juis die konsep van die wet, een van die sentrale gedagtes van Dooyeweerd se filosofie staan in die onlangse ontwikkelinge in die brandpunt. Hierdie diskussie is versnel deur die vyf en 
Elaine Botha

twintigjarige jubileumkongres van die Institute for Christian Studies in Toronto in 1992 wat as tema gehad het "The ethos of compassion" waar daar onder andere betoog is dat die Dooyeweerdiaanse konsep van die wet sterk trekke van logisisme en rasionalisme sou vertoon en daarom vervang moes word met ' $n$ meer Skrifgetroue visie waarin die etos van barmhartigheid sentraal sou staan. Juis die konfrontasie met onder andere die problematiek van homoseksualiteit en die eise wat dit stel aan 'n Christelik verantwoorde mensvisie het hierdie kentering en die diskussie in die hand gewerk.

In die posisionering ten opsigte van die diskussie oor die wet en die rol van die Skrif verteenwoordig die artikels in hierdie bundel verskeie standpunte. Van der Walt wy sy artikel aan een van die bronne van die reformatoriese visie en vestig die aandag op problematiese kante van die Kuyperiaanse begrip van skeppingsordinansies. Hy argumenteer dat daar in Kuyper se visie 'n sterker onderskeiding gemaak behoort te word tussen die Godgegewe normatiewe struktuurprinsipes en die menslike vormgewing daarvan. Van der Walt soek die bron van die problematiese fasette van Kuyper se visie in sy semideterministiese benadering wat onder meer in die hand gewerk is deur invloed van die Neo-Platonisme en die Romantiese Idealisme. Roets vestig die aandag op wat hy meen problematiese kante is van Dooyeweerd se visie op die verhouding tussen die bo-tydelike Woord van God as Christelike grondmotief en die tydelike, gediversifieerde uitdrukking van die grondmotief in die Skrif. Die assosiasie tussen die grondmotief en die bo-tydelike sfeer tipeer hy as absolutisme en bied as voorstel vir die oplossing van hierdie probleem 'n duideliker onderskeiding tussen die Christelike grondmotief en die filosofiese besinning daaroor en die sondig-menslike formulering daarvan. Bartholomew vestig die aandag op belangrike verskuiwinge aantoonbaar in die onlangse ontwikkelinge in die reformatoriese filosofie. Hierdie verskuiwinge in die visie op die wet, die rol van die Skrif en die interpretasie van die antitese beskou hy as onrusbarend.

Snyman se vergelyking van Dooyeweerd se transendentale kritiek met die negatiewe kritiek van Adorno plaas die werk van Herman Dooyeweerd in die ruimer konteks van die filosofiese besinning oor die kultuur van die Weste. Hy toon aan dat albei filosowe se werk diep gewortel is in die kultuur wat deur hulle so sterk gekritiseer word. Hy betoog dat albei tekort skiet in hulle diepgaande filosofiese kritiek en stel as alternatief vir die 
groei van Christelike denke die noodsaak van 'n deurlopende debat tussen opponerende interpretasies van die Bybelse boodskap.

Strauss plaas die diskussie oor die spanning tussen die kousaliteit en vryheid van die mens in 'n ruimer konteks deur te poog om met behulp van die analise van die elementêre grondbegrippe van enkele vakwetenskappe aan te toon dat hierdie dualisme van kousaliteit en vryheid getransendeer kan word. Hierdie analise word gedoen deur die verhouding van fisiese, historiese en logiese kousaliteit van naderby te bekyk.

In die artikels wat sterker aandag skenk aan kontemporêre kultuurproblematiek voer Botha aan dat die erkenning van die wet en die wetsorde die belangrikste beskerming bied teen die anslae van pluralisme en relatiwisme so kenmerkend van die 'wilde pluralisme' en relatiwisme in die postmodernisme. Sy stel dat Dooyeweerd se filosofie soos gewortel in die 'meta-verhaal' van die Christendom, nog steeds belangrike vertrekpunte bied vir die diskussie van kontemporêre vraagstukke.

In die artikel van Heyns word geredeneer dat die vraag na die legitimiteit van staatsgeweld nie beantwoord kan word deur 'n beroep op 'n realistiese opvatting van bepaalde momente van die struktuurorde van die staat nie, maar dat die beswaar teen staatsgeweld en gelegitimeerde geweld opgelos moet word deur die problematiek te beoordeel in die lig van die Bybelse konsep van verlossing en herstel.

Du Plessis ontwikkel ' $n$ argument ten behoewe van 'n etos van verantwoordelike rentmeesterskap. In hierdie etos sal nie die mens of die natuur sentraal staan nie, maar die poging om in die lig van die eise van verantwoordelike rentmeesterskap die belange van die samelewing met dié van die omgewing te versoen deur die interafhanklikheid van mens en natuur te beklemtoon en erkenning te gee aan die eis aan die mens om sy morele verantwoordelikheid uit te brei tot alle skepsele.

In die lig van die ontwikkelinge orals ter wêreld asook die toename in belangstelling vanuit alle wêrelddele en veral die deelname en belangstelling van jong akademici kan tot die konklusie gekom word dat die reformatoriese filosofie vitaal en produktief is. 